\title{
Logging waste of Eukaliptus ind 61 clone in industrial plantation forest, North Sumatra, Indonesia
}

\author{
Muhdi $^{1}$, Diana Sofia Hanafiah ${ }^{2}$, Asmarlaili Sahar ${ }^{3}$, Anita Zaitunah ${ }^{4}$, Ridwanti Batubara ${ }^{5}$, \\ Tommy Silaen ${ }^{6}$, Tika Yuana Sari ${ }^{7}$ \\ \{muhdi@usu.ac.id ${ }^{1 *}$,diana.hanafiah@usu.ac.id², assaharhanafiah@yahoo.com³, azitunah@gmail.com", \\ ridwantibb@yahoo.com ${ }^{5}$, tommysilaen@gmail.com ${ }^{6}$, tikayuanasari@gmail.com ${ }^{7}$ \} \\ Faculty of Forestry, Universitas Sumatera Utara, Indonesia ${ }^{1,4,5,6,7}$ \\ Faculty of Agriculture, Universitas Sumatera Utara, Indonesia ${ }^{2,3}$ \\ *muhdi@usu.ac.id
}

\begin{abstract}
The purpose of this study was to obtain the influence of height and diameter at breast height on the volume of logging waste of Eukaliptus clone ind 61. This research was carried out at industrial forests areas of PT. Toba Pulp Lestari, North Sumatra, Indonesia. Data collection consists of primary data and secondary data. Data analysis is to know the relationship of height and diameter at breast height on the volume of logging waste. The factor seen can be analyzed using multiple linear regression analysis, to determine the relationship of variables to the volume of logging waste. This research resulted that the percentage of stump waste and stem waste were $15.38 \%$ and $84.62 \%$, respectively. The results showed that regression model was $\hat{Y}=0.002 \mathrm{X} 1+0.0049 \mathrm{X} 2$ 0.01 . The increasing in height and diameter at breast height that occurs in each tree is directly proportional to the addition of logging waste volume.
\end{abstract}

Keywords: logging waste, industrial forest, diameter at breast height.

\section{Introduction}

Lack of raw materials underlies given permission to manage forests sustainably, one of which is the industrial plantation forest. Wood production from industrial plantation forest is targeted to reach 360 million $\mathrm{m}^{3}$ per year in the next 10 years, to support the forest industry. One of the activities observed in this study was timber harvesting. Timber harvesting is an effort to move log to a collection or management of wood that can increase the economic value of the wood. Forest harvesting usually produce waste, the waste can be in the form of leaves, bark, and tree branches $[1,2]$. This waste can be managed into added value, and can be resold. Eucalyptus hybrid Ind 61 clone is considered to growth well in PT. Toba Pulp Lestari areas.

According to [3], the volume of wood used tends to be smaller than the volume of wood that is felled, so there is residual wood that is not transported in logging plots or in wood collection sites. This situation is quite alarming, because on the one hand the needs wood will continue to increase and on the other hand there is a significant waste of wood.

Different criteria in defining and classifying wood harvesting waste with different conditions of the research location will produce different volumes of logging waste. For this reason, research on the identification and potential of logging waste is very much needed in 
order to extent to the prospects for the utilization of logging waste. The objective this study was to obtain the influence of height and diameter at breast height on the volume of logging waste of eukaliptus ind 61 clone.

\section{Research Method}

This research was carried out at PT. Toba Pulp Lestari, North Sumatra. Object of this research is the forest stand after the harvesting activities. Secondary data in the form of data obtained from companies that support the results of research. This secondary data is in the form of field conditions and maps of the location of cutting plots. Primary data is the main data obtained by direct observation in the field. Analysis of the relationship of some factors that influence the volume of logging waste. The factor seen is the influence of tree diameter and height on the volume of waste can be analyzed using Multiple Linear Regression Analysis, to determine the relationship of these variables to the volume of waste carried out and t test. Data analysis was performed using SPSS (Statistical Product and Service Solution) version 16.

\section{Results and Discussion}

\subsection{Volume and percentage of wood waste}

Wood waste was measured and found the volume of wood that could be used approximately, the volume of wood produced and the volume of wood parts that could not be utilized or counted as wood waste. This data is obtained by direct measurement of the diameter of the wood, both the diameter of the tip and diameter of the base. The volume of production wood is obtained from the calculation of the volume of wood that has been cleaned from the skin, stems, twigs, and ready to be sent to the factory. In order to find out the wood that has not been cleaned the numbering is carried out on the wooden waste using paint. The results of the volume of wood can be estimated, the volume of wood production and waste can be seen in Figure 1.

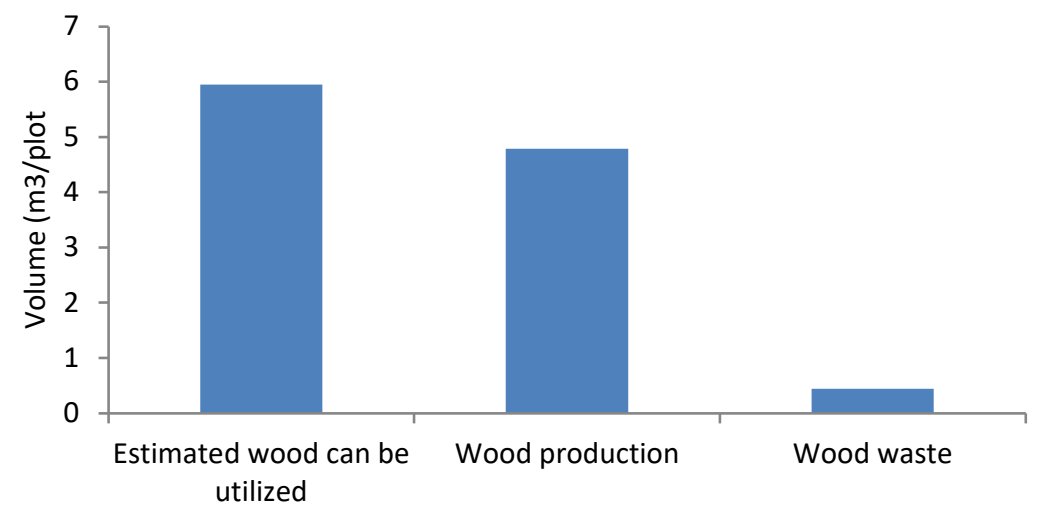

Fig. 1. Estimated wood that can be utilized, wood production and wood waste 
Figure 1 showed that the estimated volume of wood that can be utilized was $5.95 \mathrm{~m}^{3}$ and wood production was $4.79 \mathrm{~m}^{3}$, respectively. It was resulting that logging waste was $0.44 \mathrm{~m}^{3}$. The wood harvesting waste is caused by the field condition which has a moderate to steep slope, so that the chainsaw and helper operators have difficulty in cutting down. So that some tree stumps have uneven surfaces. With the condition of such areas, it is difficult for workers to determine the direction of felling notches and notches so that there are some broken woods at the top of the first branch [4,5].

The upper trunk waste comes from the first branch waste up to the tree canopy. The stump waste is the waste which is under the back notch and fall notch. For delinquent logging waste is left behind so that the soil structure in the area does not change and prevents landslides. In addition, the wood will be transported more if it is in a round shape and the compilation into trucks will be easier. To see the comparison of the volume of stem waste and the stump waste can be seen in Figure 2.

Based on investigated in the field, this waste occurs due to inefficient harvesting activities carried out or referred to as technical factors. Lack of seriousness in cutting is one of the factors that cause the arrears to be taken too long. In addition, the harvesting waste can also occur due to the determination of the wrong felling direction, thus causing the wood to break during logging. In addition, in forest harvesting activities, problems often occur because the equipment used stop working due to lack of maintenance of the forest harvesting tools [6]. According to the research by [7] and [8] resulted that the occurrence of a large amount of logging waste and residual stand damage caused by technique of felling and determining the direction of felling.

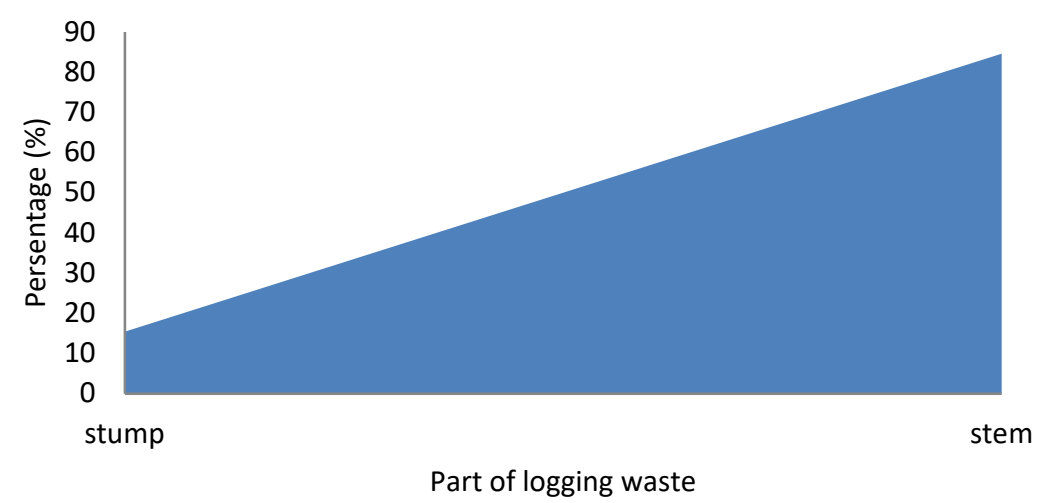

Fig. 2. The percentage of stump waste and stem waste volume.

\subsection{Interaction of plant height and diameter at breast height to waste volume}

Analysis of the data in this study was used to see the relationship between diameter at breast height and height of trees and tree volume. This data analysis was performed using statistical product service solution (SPSS) software. All data obtained are included in SPSS with the independent variable being the height and diameter of the tree while the dependent variable is the volume of waste. This data analysis was performed with a $95 \%$ confidence interval. Significance value is below 0.05 means that the independent variables significantly influence the dependent variable. To see the correlation model in each replication plot can be seen in Table 1. 
Table 1. Effect of height and diameter at breast height on logging waste volume

\begin{tabular}{lcc}
\hline Regression model & R-square (\%) & Significance \\
\hline$\hat{\mathrm{Y}}=0.002 \mathrm{X}_{1}+0.0049 \mathrm{X}_{2}-0.01$ & 62 & $3 \times 10^{-29}$ \\
\hline
\end{tabular}

Based on the regression model $\hat{Y}=0.002 \mathrm{X} 1+0.0049 \mathrm{X} 2-0.01$, it can estimated that the plant height and diameter at breast height of the tree has a positive effect on the increase in the volume of logging waste, meaning that each increase in height and diameter at breast height of the tree will increase the volume of logging waste. In other words, the increase in height and diameter at breast height that occurs in each tree is directly proportional to the addition of logging waste volume in the cutting plot. This was also stated by [4] in general logging waste was caused by two factors, namely natural factors and technical factors. In this study, natural factors that influence the amount of logging waste are topography, stand density, wood dimensions, wood species, soil conditions and weather conditions. For this reason, special attention needs to be paid to waste utilization, where there are many types of wood processing such as particle boards, fiber boards or other types of boards using the raw material for harvesting waste itself. It has been proven by [9], where logging waste of Acacia mangium can be used as a non-structural particle board such as furniture.

\section{Conclusion}

The plant height and diameter at breast height of the tree has a positive effect on the increase in the volume of logging waste, meaning that each increase in height and diameter at breast height of the tree will increase the volume of logging waste. In other words, the increase in height and diameter at breast height that occurs in each tree is directly proportional to the addition of logging waste volume in the cutting plot.

\section{Acknowledgment}

Thanks to the Ministry of Technology Research and Higher Education that have funded this research through the PTUPT DRPM DIKTI scheme in 2019. Also Thanks to PT Toba Pulp Lestari for facilitating this research.

\section{References}

[1] Mansur, A., Tirkaamina, M., Sutidjo, H. Harvesting waste and exploitation factors of IUPHHK-HA PT. Rizki Kacida Reana Paser Regency, East Kalimantan Province. Agrifor Journal. (2013). 
[2] Matangaran, J.R., Partiani, T., Purnamasari, R. Exploitation and qualification factors of wood waste in the framework of increasing efficient harvesting of natural forests. Journal of Sustainable Earth. (2013).

[3] Muhdi. Logging waste due to timber harvesting techniques in tropical natural forests. Kultura Journal. (2003).

[4] Partiani, T. Logging waste and exploitation factors in PT. Salaki Suma Sejahtera, Siberut Island, West Sumatra. Faculty of Forestry IPB. Bogor. (2010).

[5] Puspitasari, D. Logging waste and exploitation factors in Industrial Plantation Forest Exploitation Case Study at HPHTI PT. Musi Hutan Persada, South Sumatra. Faculty of Forestry IPB. Bogor. (2013).

[6] Muhdi, A Sahar, D S Hanafiah, A Zaitunah and F W B Nababan. Analysis of biomass and carbon potential on eucalyptus stand in industrial plantation forest, North Sumatra, Indonesia. IOP Conference. (2019).

[7] Sasmita, R.L. Natural Forest Harvesting Waste in Indonesia. Faculty of Forestry IPB. Bogor. (2003).

[8] Purwoko A, Muhdi, Hanafiah AS. Residual stand damages caused by conventional and reduced impact timber harvesting in the natural forest. International Journal of Mechanical Engineering and Technology. (2018).

[9] Muhdi., Risnasari, I and Putri, L.A.P. Study of particle boards from logging waste of Acacia mangium.L. Journal of Life and Physical Sciences. (2013). 